\title{
Yenidoğan Yoğun Bakım Ünitesinde Anne Sütui ve Hijyen Eğitiminin Yatan Hasta Memnuniyetine Etkisi
} \author{
Neonatal Intensive Care Unit \\ Meltem Karabay ${ }^{1}$, Gülsüm Kaya ${ }^{2}$, İbrahim Caner ${ }^{1}$, Oğuz Karabay ${ }^{2}$ \\ ${ }^{2}$ Sakarya Üniversitesi Eğitim ve Araştırma Hastanesi, Enfeksiyon Kontrol Komitesi, Sakarya \\ Yazışma Adresi / Correspondence: \\ Meltem Karabay \\ Adnan Menderes Caddesi Sağlık Sokak No: 195 Adapazarı, Sakarya \\ T: +905056702693 E-mail : meltemkarabay@yahoo.com \\ Geliş Tarihi / Received : 22.07.2019 Kabul Tarihi / Accepted : 10.12.2019 \\ Orcid : \\ Meltem Karabay https://orcid.org/0000-0002-5322-2972 \\ Gülsüm Kaya https://orcid.org/0000-0003-2517-5512 \\ İbrahim Caner https://orcid.org/0000-0002-6756-122X \\ Oğuz Karabay https://orcid.org/0000-0003-1514-1685 \\ ( Sakarya Tip Dergisi / Sakarya Med J 2019, 9(4):693-697) DOI: 10.31832/smj.595338
}

Effects of Breast Milk and Hygiene Training on Inpatient Satisfaction in

${ }^{1}$ Sakarya Üniversitesi, Tip Fakültesi, Çocuk Sağlığı ve Hastalıkları Anabilim Dalı, Neonatoloji Bilim Dalı, Sakarya

*Bu çalışma 3-7 Nisan 2019 tarihleri arasında gerçekleșen 27.Ulusal Neonatoloji Kongresi’nde poster bildiri olarak sunulmuștur.

$\ddot{\mathrm{O} z}$

Amaç Anne sütï (AS) ile beslenme, bebek mortalite ve morbiditesini azaltmada önemlidir. AS’yi hazırlarken veya anne emzirmeye hazırlanırken hijyen kurallarına uyması gelişebilecek enfeksiyonların önlenmesinde önemlidir. Çalıșmamızda yenidoğan yoğun bakım ünitesi (YDYBÜ)'nde annelere verilen AS ve hijyen eğitimi (ASHE) sonrası memnuniyet araștırılması amaçlandı.

Gereç ve Çalışma Sakarya Üniversitesi Eğitim ve Araștırma Hastanesi (SÜEAH) YDYBÜ de 1 Ocak 2016-1 Ocak 2017 tarihleri arasında yapıldı. Çalışmanın etik onayı Sakarya Yöntemler Üniversitesi Tip Fakültesi girișimsel olmayan etik kurulundan alındı. YDYBÜ'de yatarak tedavi gören yenidoğanların annelerine ASHE, video eğitimi olarak verildi. Eğitim sonrası, gönüllü annelerden görüșme formu doldurması istendi. Görüșme formunda annenin yaș ve eğitim bilgilerini içeren demografik sorular ve video eğitimin memnuniyetini içeren sorular soruldu. Memnuniyet düzeyi değerlendirmesinde, en düșük memnuniyet puanı 0 olup en yüksek memnuniyet puanı 10 idi. Elde edilen veriler SPSS 21 programında analiz edildi, $\mathrm{p}<0,05$ anlamlı kabul edildi.

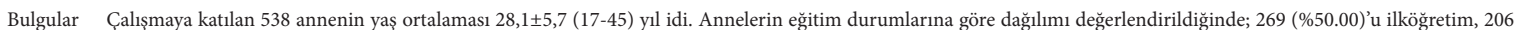

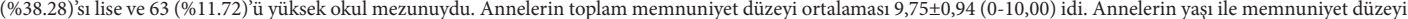
değerlendirildiğinde yaş arttıkça da memnuniyetlerinin de arttı̆̆ı belirlendi ( $\mathrm{p}=0,049, \mathrm{r}=0,085)$.

Sonuç Basit eğitimlerle anneler eğitilebilir ve standardize edilmiș eğitimler anne ve çocuk bakımının kalitesini arttırmak amacıyla kullanılabilir.

Anahtar anne sütü; emzirme; hijyen eğitimi; yenidoğan yoğun bakım ünitesi; anneler; memnuniyet düzeyi

kelimeler

Abstract

Objective Feeding with breast milk (BM) is important in reducing infant mortality and morbidity. Compliance with hygiene rules when preparing BM or preparing for breastfeeding is important in preventing infections that may develop. The aim of this study was to investigate the satisfaction of mothers after breastfeeding and hygiene education (BFHE) in the neonatal intensive care unit (NICU).

Materials This study was conducted between January 1, 2016 and January 1, 2017 at Sakarya University Training and Research Hospital NICU. Ethical approval of the study was obtained from the and Methods interventional ethics committee of Sakarya University Faculty of Medicine. Mothers of patients in the NICU were given BFHE video training. After the training, volunteer mothers were asked to fill out the interview form. Demographic questions about the age and education of the mother and questions about the satisfaction of the video training were asked in the interview form. In the satisfaction level assessment, the lowest satisfaction score was 0 and the highest satisfaction score was 10 . The obtained data were analyzed in SPSS 21 program, $p<0,05$ was considered significant.

Results The mean age of the 538 mothers included in the study was 28,1 $\pm 5,7$ (17-45) years. When the distribution of the mothers according to their educational status was evaluated; 269 (50.00\%) of them were primary school, $206(38.28 \%)$ of them were high school and $63(11.72 \%)$ were university graduates. Mean satisfaction level of mothers was 9,75 $\pm 0,94(0-10.00)$. When the age and satisfaction level of the mothers were evaluated, it was determined that as the age increased, their satisfaction increased $(p=0,049, r=0,085)$.

Conclusion Mothers can be trained with simple trainings and standardized trainings can be used to improve the quality of mother and child care.

Key words $\quad$ breast milk; breastfeeding; hygiene; education; neonatal intensive care unit; mothers; satisfaction level 


\section{GIIRIŞ}

Bebek için en üstün beslenme yöntemi anne sütü (AS)'dür. AS ile beslenme, bebeklere yaşam için iyi bir başlangıç sunmakta, mortalite ve morbidite oranlarını düşürmekte ve hastalıkları önlemede kilit rol oynamaktadır. Bebeğin fiziksel, ruhsal ve zihinsel gelişimi için gerekli olan sıvı, enerji ve besin öğelerini içeren AS; biyoyararlanımı yüksek, sindirimi kolay, doğal bir besindir. Bebeğin gelişimine katkı sağlamasının yanı sıra, içerdiği immünglobülinlerin bebeği birçok hastalıktan koruduğu ve bağışıklık sistemini güçlendirerek egzama, astım gibi alerjik reaksiyonlar, diyabet, koroner arter hastalığı gibi kronik hastalıklar ve lenfoma gibi bazı kanserlerden koruduğu çalışmalarda gösterilmiştir. ${ }^{1-10} \mathrm{AS}$, yenidoğanların tüm gereksinimlerini karşılayan en uygun besindir ve yerini alacak hiçbir ideal besin yoktur. ${ }^{1,5,6,11}$ AS, inek sütü ya da mama kullanımına göre daha ekonomik olup hazırlama ve saklama sorunu yoktur. AS her zaman hazır ve temiz olmasının yanı sıra bakteriyostatik özelliği vardır. ${ }^{5,12}$ DSÖ, bebeklerin doğumdan itibaren ilk altı ay boyunca yalnızca AS almalarını, altıncı aydan sonra ek besinlerle beraber AS ile beslenmeye iki yaş ve ötesine kadar devam edilmesini önermektedir. ${ }^{13}$ AS’nin içeriği hep aynı kalmamakta, kişiden kişiye farklılık gösterdiği gibi prematür doğum yapan annelerde de bebeğin matürasyonuna uygun bir özellik taşımaktadır. Genellikle preterm bebekler ve sorunlu yenidoğanlar uzun süre yoğun bakım ünitelerinde takip edilmektedir. Doğrudan bebeğe ulaşamadığı durumlarda anne, bebeğine steril koşullarda AS sağıp göndermekte ve yenidoğan beslenebilmektedir. AS'yi hazırlarken veya anne emzirmeye hazırlanırken hijyen kurallarına uyması gerekmektedir. ${ }^{14}$ Mikroorganizma bulaşan AS, miadında veya prematüre yenidoğanlarda enfeksiyonlara yol açmaktadır. Kontamine AS’nin yenidoğanlarda Grup B Streptokok, CMV, HIV, Salmonella, Brusella gibi bir çok enfeksiyona neden olabileceği çeşitli araştırmalarda gösterilmiştir. ${ }^{19,20}$ Başarılı bir emzirme sürecinin yaşanması için annelerin emzirme ve AS hakkında bilgilendirilmeleri oldukça önemlidir. ${ }^{15}$ Annenin emzirme, süt sağma ve AS’yi hazırlama işlemlerinden önce el hijyeni sağlaması ve hijyen kurallarına uyması gelişebilecek enfeksiyonların önlenmesinde önemlidir. ${ }^{16-18}$ Annelerin emzirmeye başlamaları ve başarıyla devam ettirebilmeleri için bilgi ve desteğe ihtiyaçları vardır. Annelere AS, emzirme ve hijyen eğitimi konusunda eğitimli sağlık çalışanları tarafından sağlanan destekle, annenin bebeğini sadece AS ile besleme süresini arttırdığ bildirilmiştir. $^{7}$

Bu çalışma, yenidoğan yoğun bakım ünitesi (YDYBÜ)'nde tedavi gören yenidoğanların annelerine verilen AS ve hijyen eğitimi (ASHE)'nin anne memnuniyetine etkisini belirlemek amacıyla yapılmıştır.

\section{GEREÇ ve YÖNTEMLER}

Tanımlayıcı nitelikte bir araştırma olarak tasarlanan çalışmanın verileri, Sakarya Üniversitesi Eğitim ve Araştırma Hastanesi (SÜEAH) YDYBÜ'de 1 Ocak 2016-1 Ocak 2017 tarihleri arasında retrospektif olarak derlenen verilerden elde edildi. SÜEAH YDYBÜ 1. 2. ve 3. düzey olmak üzere toplam 44 kuvöze sahiptir. YDYBÜ'sinde yatarak tedavi gören yenidoğanların annelerine ASHE verildi. Enfeksiyon kontrol tedbirleri çerçevesinde hazırlanan ASHE, video eğitimi olup toplam $15 \mathrm{dk}$. sürmekteydi. ASHE'de annelere hijyen alışkanlıkları, meme bakımı ve AS hijyeni ile ilgili bilgiler verildi.

Görüşme formu, annenin yaş ve eğitim bilgilerini içeren iki demografik soru, araştırmacı tarafından literatür taranarak oluşturulan ve ASHE'nin memnuniyetinin değerlendirilmesine yönelik beş soru olmak üzere yedi sorudan oluşmaktaydı. Memnuniyet düzeyini belirlemede yer alan sorulara verilecek cevaplar görüşme formunda katılıyorum (1) ve katılmıyorum (0) şeklinde kodlandı. Çalışmaya katılmayı kabul eden annelerden ASHE sonrası görüşme formunu doldurması istendi.

Annelerin YDYBÜ'de bebeğinin yatarak tedavi görmesi, ASHE alınması ve çalışmaya katılmayı kabul etmesi çalışmaya dahil olma kriterlerini oluştururken; dışlanma kriterlerini de bebeğinin YDYBÜ'de yatarak tedavi görmemesi, ASHE almaması ve çalışmayı kabul etmemesi 
durumları oluşturdu. Mesai saatleri dışında üniteye gelen ve çalışmaya katılmayı kabul etmeyen anne sayısı 943 idi. Çalışmanın etik onayı Sakarya Üniversitesi Tıp Fakültesi girişimsel olmayan etik kuruldan alındı (10.01.2018 tarih ve 13 say1).

Elde edilen verilerin istatistiksel olarak değerlendirilmesi SPSS 21 programında yapıldı. Kategorik değişkenlerin gösteriminde sayı ve yüzde, sayısal değişkenlerin gösterimi aritmetik ortalama, standart sapma ve minimum-maksimum değer kullanıldı. Çalışma verileri değerlendirilirken tanımlayıcı istatistiksel incelemelerde, Normallik testleri Kolmogorov Smirnov ve Shapiro Wilk ile Spearman Korelasyon analizi kullanıldı. Memnuniyet düzeyi değerlendirmesinde, en düşük memnuniyet puanı 0 olup en yüksek memnuniyet puanı 10 idi. İstatistiksel anlamlılık düzeyi $\mathrm{p}<0,05$ olarak alınd .

\section{BULGULAR}

Çalışmaya katılan 538 annenin yaş ortalaması 28,12 $\pm 5,71$ $(18,00-45,00)$ yıldı. Annelerin eğitim durumlarına göre dağılımı değerlendirildiğinde; 269 (\%50,00)'u ilköğretim, $206(\% 38,28)$ 'sı lise ve $63(\% 11,72)$ 'ü yüksek okul mezunuydu. Annelerin toplam memnuniyet düzeyi ortalaması 9,75 $\pm 0,94(0-10,00)$ idi.

\begin{tabular}{|l|c|c|}
\hline \multicolumn{3}{|l|}{ Tablo 1. Annelerin görüşme formunda sorulan sorulara ver- } \\
dikleri cevaplar \\
\hline Sorular & $\begin{array}{c}\text { Evet } \\
\text { (n:538) }\end{array}$ & $\%$ \\
\hline $\begin{array}{l}\text { İzlemiş olduğunuz eğitim videosundaki } \\
\text { bilgiler anlaşlır mıydı? }\end{array}$ & 521 & 96,84 \\
\hline $\begin{array}{l}\text { Eğitim videosunun görüntü ve ses kalitesi } \\
\text { yeterli miydi? }\end{array}$ & 527 & 97,96 \\
\hline $\begin{array}{l}\text { Aldığınız eğitim anne sütü ve hijyen bilginizi } \\
\text { arttırdı mı? }\end{array}$ & 526 & 97,77 \\
\hline Yapılan eğitim sizi memnun etti mi? & 527 & 97,96 \\
\hline $\begin{array}{l}\text { Videolardan öğrendiğiniz bilgileri günlük } \\
\text { hayatta uygulamayı düşünüyor musunuz? }\end{array}$ & 537 & 99,81 \\
\hline
\end{tabular}

Annelerin sorulara verdikleri cevaplar Tablo 1'de gösterildi. Annelerin yaşı ile memnuniyet düzeyi değerlendirildi- ğinde yaş arttıkça memnuniyetlerinin de arttığı belirlendi $(\mathrm{p}=0,049, \mathrm{r}=0,085)$ (Tablo 2).

\begin{tabular}{|c|c|c|c|}
\hline Değişken & $\mathrm{N}$ & $\mathrm{r}$ & $\mathrm{p}$ değeri \\
\hline Yaşa göre memnuniyet & 538 & 0,085 & 0,049 \\
\hline
\end{tabular}

Öğrenim durumuna göre memnuniyet düzeyi arasında anlamlı bir fark yok idi ( $\mathrm{p}=0,799)$ (Tablo 3).

\begin{tabular}{|c|c|c|}
\hline \multicolumn{3}{|c|}{$\begin{array}{l}\text { Tablo 3. Annelerin öğrenim düzeyine göre memnuniyet } \\
\text { düzeyleri }\end{array}$} \\
\hline Öğrenim düzeyi & $\begin{array}{c}\text { Puan ortalaması } \pm \text { SS } \\
(\text { min-max })\end{array}$ & $\mathrm{p}$ değeri \\
\hline İlköğretim & $9,75 \pm 0,87(4,00-10,00)$ & \multirow{3}{*}{0,799} \\
\hline Lise & $9,75 \pm 0,96(0-10,00)$ & \\
\hline Yüksek Okul & $9,74 \pm 1,16(2,00-10,00)$ & \\
\hline $\begin{array}{l}\text { SS: Standart sapn } \\
\text { değer }\end{array}$ & nimum değer; max: ma & \\
\hline
\end{tabular}

\section{TARTIŞMA}

$\mathrm{Bu}$ araştırmada AS’nin hijyen kalitesini artıracak görsel video eğitimin etkinliği emziren 538 anne üzerinde araştırılmış ve annelerin yaklaşı \%98'inin bu video eğitimin hijyen düzeyini arttırdığı ve buradan elde ettiği bilgileri günlük pratiğe uygulayacağını bildirmiştir. Verilen eğitimden elde edilen memnuniyet düzeyi değerlendirildiğinde, annelerin eğitim düzeyine göre memnuniyet düzeylerinde anlamlı fark olmasa da, anne yaşı arttıkça memnuniyet düzeyinin anlamlı olarak arttığı saptanmıştır.

AS, bebek için vazgeçilmezdir. Ancak, AS hijyenik bir şekilde elde edilemez ve saklanamazsa bebek için riskli hale gelebilmektedir. Özellikle YDYBÜ'de AS’nin kontaminasyonu önemlidir. 2010 yılında sunulan bir araştırmada dondurulmuş AS’nin steril olmadığı gösterilmiştir. Çalışmada, 800'ü aşkın örneğin analizinde AS'nin \%22'sinde bakteri üremezken, \%87'sinin stafilokoklarla kolonize olduğu saptanmıştır. ${ }^{21}$ AS’nin kontaminasyonu yenidoğanı enfekte edebilir. AS’nin kontaminasyonuna bağlı gelişen 
septisemi ciddi mortalite ve morbidite nedenidir. Widger ve arkadaşlarının çalışmalarında, dondurulmuş AS ile beslenmeye bağlı üç geç başlangıçlı yenidoğan sepsisi bildirmiştir. Sepsisli ikiz vakalardan biri kaybedilmiştir. İkizlerin kanında ve AS örneğinde aynı direnç ve duyarlılığa sahip E.coli üremiştir. Üçüncü sepsis vakası ise preterm bir bebek olup kan ve AS'de aynı direnç ve duyarlılık paternine sahip Klebsiella pneumoniae üremiştir. Bu sepsis etkenlerinin bakım verilen ortamdan alındığı ve bu etkenlerin de AS’ye bulaştıkları bildirilmiştir. ${ }^{22}$

Anneler, bebeklerinin sağlığı söz konusu olduğunda çok daha dikkatli olmakta, her türlü fedakarlığa ve özveriye açık hale gelmektedirler. Bu araştırmada da benzer bulgulara ulaştık. Annelerin, AS kalitesini ve hijyenini arttırmaya yönelik eğitimlere açık ve istekli olduğunu saptadık. Üstelik annelere "Aldığınız eğitim AS ve hijyen bilginizi arttırdı mı?" diye sorulduğunda annelerin \%98'i bu eğitimin bilgi düzeyini arttırdığını belirtti. Bu bulgular açık bir şekilde göstermektedir ki anneler, AS’nin kalitesini arttıracak ve bebeklerinin güvenliğine katkı sağlayacak her türlü eğitime açıktır. Yeter ki annelere bu imkân verilsin.

Annelerin emzirmeye başlamaları ve başarıyla devam ettirebilmeleri için bilgi ve desteğe ihtiyaçları vardır. Annelere AS, emzirme ve hijyen eğitimi konusunda eğitilmiş sağlık çalışanları tarafından sağlanan destekle bebek sağlığı korunabilir. Video eğitimler birçok alanda kullanılmaktadır. Biz de çalışmamızda basit video eğitimini hijyenik AS elde etmek amacıyla kullandık. Bu çalışmadan elde ettiğimiz gözlemler, annelerin bu eğitimleri faydalı bulduğu ve sonraki dönemlerde eğitimden edindikleri bilgileri kullanmalarıydı. Dolayısıyla basit video eğitimleri bu amaçla kullanılabilir.

Annelerin tamamına yakını aldıkları AS ve hijyen eğitiminden memnun olduklarını ifade etmiş ve memnuniyet düzeyi puan ortalamaları yüksek bulunmuştur. Çalışmamızda ASHE memnuniyet düzeyi puanı ortalaması 9,75 $\pm 0,94$ (0-10) idi. Benzer bir çalışmada hastane- de annelere verilen doğum sonu bakımdan memnuniyet düzeyinin araştırıldığı çalışmada annelerin memnuniyet düzeyini ortalama 7,1 $\pm 2,1$ (0-10) puan olarak bildirmişlerdi. ${ }^{23} \mathrm{Bu}$ araştırmada, anne yaşı ile memnuniyet düzeyi arasında pozitif yönde güçlü bir ilişki olduğu, yaş arttıkça memnuniyetin de arttığını saptadık. Annelerin yaşı arttıkça eğitimin önemi hakkında farkındalığın daha da arttığını ve eğitimleri önemsediğini gözlemledik. Bu durum AS hijyenine gösterilen önemin anne yaşı ile ilgili olduğunu düşündürmüştür. Annenin ne kadar tecrübesi artarsa, o kadar bebek bakımını ve AS hijyenini önemsediğini düşündük.

Araştırmamızda anne eğitim düzeyi ile memnuniyet arasında ilişki bulunmamıştır. Bu durum farklı nedenlere bağlı olabilir. Bu nedenlerden biri; tüm eğitim gruplarında memnuniyetin çok yüksek düzeyde olması, diğeri ise anneliğin kısmen de olsa içgüdüsel olmasına bağlı olabilir. ${ }^{24}$ Sonuç olarak; basit ve standardize edilmiş eğitimlerle annelerin eğitilebileceği, AS ve bebek bakımının kalitesini arttırmak amacıyla bu eğitimlerin kullanılabileceğini düşünüyoruz. Ayrıca basitleştirilmiş video eğitimleriyle AS'nin hijyen düzeyi artırılabilir. Üstelik bu anneler, basitleştirilmiş eğitimlerden elde ettiği bilgileri günlük pratiğe uygulayabilirler. 
Sakarya Tip Dergisi 2019;9(4):693-697

KARABAY ve Ark., Anne Sütü ve Hijyen Eğitiminin Hasta Memnuniyetine Etkisi

\section{Kaynaklar}

1. Lönnerdal B, Erdmann P, Thakkar SK, Sauser J, Destaillats F. Longitudinal evolution of true protein, amino acids and bioactive proteins in breastmilk: a developmental perspective, Journal of Nutritional Biochemistry 2017; 41: 1-11.

2. Lok KYW, Chau PH, Fan HSL, Chan KM, Chan BH, Fung GPC. et al. Increase in weight in low birth weight and very low birth weight infants fed fortified breast milk versus formula milk: A retrospective cohort study, nutrients, 2017;9: 520.

3. Selimoğlu MA. Anne sütü ile beslenmenin ileri yaşama etkileri. Türk Pediatri Arşivi. 2010; 45: 309-14.

4. Can Ș, Ünülü M. Annelerin süt annelik ve anne sütü bankacllğı hakkındaki bilgi düzeyleri, Ankara Med J, 2019;(1):60-70.

5. Çakmak S, Demirel Dengi AS. Postpartum dönemdeki annelerin emzirme ve anne sütünün önemi hakkndaki bilgilerinin değerlendirilmesi, Türk Aile Hek Derg 2019;23:9-19.

6. Başer DA, Sönmez CI, Arslan M. Kocaeli ilindeki aile hekimleri ve aile sağlğ̆ elemanlarının anne sütü ve emzirme ile ilgili bilgi düzeyleri, Konuralp Tip Dergisi 2018;10:34-40.

7. İnanç BB. 15-49 yaş arası annelerin anne sütü ile ilgili uygulamaları ve etki eden faktörler. Turkiye Aile Hekimligi Dergisi. 2013; 17: 51-5.

8. Kural B, Gökçay G. Anne-bebek ikilisinin birlikte uyumast ve anne sütü ile beslenme, İst Tip Fak Derg 2018; 81: 62-6.

9. Andreas NJ, Kampmann B, Mehring Le-Doare K. Human breast milk: A review on its composition and bioactivity. Early Hum Dev 2015; 91: 629-35.

10. Walker A. Breast milk as the gold standard for protective nutrients, J Pediatr. 2010;156(2 Suppl):S3-7.

11. Erick M. Breast milk is conditionally perfect, Med Hypotheses. 2018;111:82-89.

12. Eglash A, Simon L. ABM Clinical Protocol \#8: Human milk storage information for home use for full-term infants, Revised 2017, Breastfeed Med. 2017;12:390-395.

13. Bilgen H, Kültürsay N, Türkyllmaz C. Türk Neonatoloji Derneği sağllkl term bebeğin beslenmesi rehberi, Turk Pediatri Ars 2018; 53(Suppl 1): S128-S137.

14. Borges MS, Olivera AMM, Hattori WT, Abdallah VO. Quality of human milk expressed in a human milk bank and at home, J Pediatr (Rio J). 2018;94:399-403.
15. Demirtas ZG, Celik R. Emziren annelerin emzirme bilgilerinin kaynaklarinin incelenmesi: instagram örneği - emziren annelerin emzirme bilgilerinin kaynaklarinin incelenmesi: instagram örneği. Mehmet Akif Ersoy Üniversitesi Sosyal Bilimler Enstitüsü Dergisi. 2017; $375-88$.

16. Sosa R, Barness L. Bacterial growth in refrigerated human milk. Am J Dis Child 1987;141:111-112.

17. Haiden N, Pimpel B, Assadian O, Baglayıcı CI, Kreissl Bir, Thanhauser M. et al. Comparison of bacterial counts in expressed breast milk following standard or strict infection control regimens in neonatal intensive care units: Compliance of mothers does matter. J Hosp Infect 2016;92:226-228.

18. Pardou A, Serruys E, Mascart-Lemone F, Dramaix M, Vis HL. Human milk banking: Influence of storage processes and of bacterial contamination on some milk constituents. Biol Neonate 1994;65:302-309.

19. Jawa G, Hussain Z, Silva O. Recurrent Late-Onset Group B Streptococcus Sepsis in a Preterm Infant Acquired by Expressed Breastmilk Transmission: A Case Report, Breastfeed Med. 2013;8:134-6.

20. Zuppa AA, Antichi E, Fracchiolla A, Carducci C, Catenazzi P, Romagnoli C. Breastfeeding and infectious diseases: state of the art, Minerva Pediatr. 2010;62:397-409.

21. Civaldi E, Garofali F, Tzialla C, Paolllo P, Bollani L, Stronati M. Microorganisms in human milk: lights and shadows, J Matern Fetal Neonatal Med, 2013; 26(S2): 30-34.

22. Widger J, O'Conneli H, Stack T. Breast milk causing neonatal sepsis and death, Clin Microbiol Infect. 2010;16:1796-8.

23. Gürcüoğlu EA, Vural G. Annelerin Dogum Sonu Donemde Hastanede Verilen Ebelik/ Hemsirelik Bakimindan Memnuniyetleri. Gazi Medical Journal. 2018; 29. DOI:10.12996 gmj.2018.08.

24. Cescutti-Butler L, Hemingway A, Hewitt-Taylor J. 'His tummy's only tiny' - Scientific feeding advice versus women's knowledge. Women's experiences of feeding their late preterm babies. Midwifery. 2019;69:102-9. 